Research Article

\title{
Settlement Behavior of Soft Subgrade Reinforced by Geogrid-Encased Stone Column and Geocell-Embedded Sand Cushion: A Numerical Analysis
}

\author{
Jia-Jun Gao $\mathbb{D}^{1},{ }^{1}$ Hui Xu $\mathbb{D}^{1},{ }^{1}$ Jian-Wen Qian $\mathbb{D},{ }^{1}$ Yi-Fan Gong $\mathbb{D},{ }^{1}$ Liang-Tong Zhan $\mathbb{D},{ }^{2}$ \\ and Ping Chen $\mathbb{B}^{1}$ \\ ${ }^{1}$ School of Civil Engineering and Architecture, Zhejiang Sci-Tech University, Hangzhou 310018, China \\ ${ }^{2}$ Department of Civil Engineering, Zhejiang University, Hangzhou 310058, China \\ Correspondence should be addressed to Hui Xu; xuhui@zstu.edu.cn
}

Received 21 August 2020; Revised 5 November 2020; Accepted 17 November 2020; Published 29 November 2020

Academic Editor: Qiang Tang

Copyright (c) 2020 Jia-Jun Gao et al. This is an open access article distributed under the Creative Commons Attribution License, which permits unrestricted use, distribution, and reproduction in any medium, provided the original work is properly cited.

\begin{abstract}
The geosynthetic-encased vertical column and geosynthetic-embedded horizontal cushion are recognized as the effective methods to reduce the settlement of the soft subgrade. This paper investigated the settlement behavior of a soft subgrade reinforced by geogrid-encased stone column and geocell-embedded sand cushion using the finite element analysis method (Plaxis 2D). The simulating settlement was in good agreement with the field monitoring data, indicating the reasonability of the designed model and adopted parameters. After that, the factors, geocell layer in sand cushion, encasement length around stone column, and standing time between embankment filling stages, were employed to study their influences on the subgrade settlement. The results showed that the embedment of geocell reduced construction settlement, postconstruction settlement, and differential settlement is attributed to the increase in stiffness of sand cushion and therefore the uniform distribution of additional stress on subgrade surface. When the encasement length of stone column increased from $1 \mathrm{D}$ (one time the column diameter) to $8 \mathrm{D}$ (full encasement), the settlement in construction stage and postconstruction stage decreased by $32.2 \%$ and $35.1 \%$, respectively, which is benefited from the increase in the compression modulus of the column. The maximum lateral deformation occurred at the position of about 2D from the top of the stone column, and it decreased more significantly when the encasement length increased from 1D to 4D than that from $4 \mathrm{D}$ to $8 \mathrm{D}$. The encasement length up to $4 \mathrm{D}$ is found to be adequate in reducing the subgrade settlement and the column lateral deformation based on the consideration of performance and economy. The extension of the filling interval increased the construction settlement caused by soil consolidation, while it decreased the postconstruction settlement.
\end{abstract}

\section{Introduction}

There are large areas of soft soil ground distribution in China, especially in coastal regions, as shown in Figure 1. The soft soils are mostly silt, silty clay, and clay, which have the typical properties of being very low in stiffness, very weak in shear strength, and very small in hydraulic conductivity [1]. Many infrastructure projects, such as road embankments, have been constructed in these regions. In order to meet the requirements of load-bearing capacity and settlement control of the subgrade, the soft soil ground is necessary to be improved.
There are a number of techniques for the improvement of soft soil ground, such as stone columns (granular piles), vacuum preconsolidation, soil cement columns, lime treatment [2], and foundation replacement [3-6]. Among all these methods, the stone column technique is preferred due to the advantages of increasing bearing capacity, accelerating consolidation process, reducing final settlement, and being relatively cost-effective $[7,8]$. However, the construction of stone columns in very soft soil with low undrained shear strength is difficult due to insufficient lateral support of the surrounding soil. It is known that the most probable failure mechanism is bulging failure [7], which will lead to the 


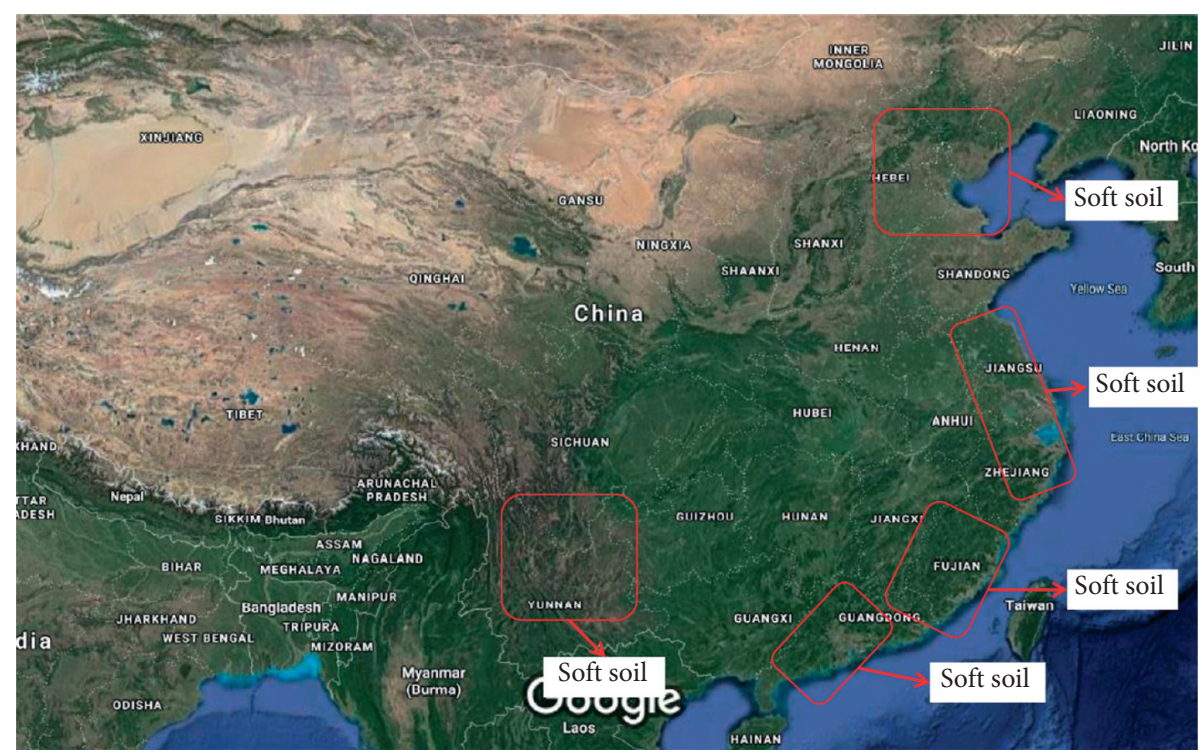

Figure 1: Distribution of soft soil ground in China.

destruction of the embankment [9-11]. To solve the problem, the concept of geosynthetic-encased stone column (GESC) has been proposed in 1989 [2]. The geosynthetic encasement could not only increase the strength of the stone column and prevent the lateral squeezing of stones but also enable quicker and more economical installation [7].

In the recent decades, many numerical and experimental studies have been carried out to focus on the performance of GESC. Fattah and Majeed [12-15] investigated the behavior of soft soil ground reinforced with original stone column (OSC) and GESC. The parameters, different spacing distance between stone columns, length to diameter ratio, shear strength of the surrounding soil, and the area replacement ratio, were employed to study their effects on the bearing improvement and settlement reduction. Kwa et al. [16] experimentally investigated the behavior of GESC for reinforcing of soft clay and found that the ultimate bearing capacity of GESC is 1.6 times compared to OSC. Malarvizhi and Ilamparuthi [17] conducted small-scale tests to investigate the improved performance of GESC and found that the ultimate bearing capacity of GESC treated beds is three times that of the untreated beds. Gu et al. [18] also found that the ultimate load capacity of the soft soil was greatly increased by GESC, and the effective length of the encasement was three to four times of the diameter of stone columns. Orekanti and Dommaraju [8] conducted strain-restricted compression tests on GESC, and the results showed that GESC with lateral reinforcement of end-bearing type and floating type showed a substantial increase in load-carrying capacity relative to clay by 2.44 and 2.01 times, respectively. Hajiazizi and Nasiri [19] experimentally investigated the behavior of ordinary stone column (OSC) and GESC for reinforcing of sand slopes and found that location of GESC in middle of the slope increases the bearing capacity of slope crown 2.17 times than OSC. Ayadat and Hanna [20] and Yoo and Lee [21] performed experimental investigation on the load-carrying capacity and settlement of GESC and concluded that additional confinement provided by the encasement not only increased the ultimate carrying capacity of the stone column but also reduced the settlement of the soft ground as compared to conventional stone columns. Similar results were also reported in the works of Murugesan and Rajagopal [7] and Kadhim et al. [22]. Almeida et al. [23] presented the behavior and instrumentation results for a test embankment on soft soil improved by GESC and found that the differential settlement between column and surrounding soil increased as the embankment height increased and consolidation progressed.

The previous studies have obtained many valuable findings for a deep understanding of the performance of GESC in improving the soft ground. However, most of these studies were carried out on a single GESC, and the behavior of GESC might be different in actual engineering. In this study, the settlement behavior of a soft subgrade reinforced with GESC and geocell-embedded sand cushion was investigated by using Plaxis $2 \mathrm{D}$ program. The numerical model was verified using the monitoring data from a soft subgrade improvement engineering. A parametric study was then conducted to study the influencing factors on the settlement behavior of the soft subgrade, including geocell layer in sand cushion, encasement length around stone column, and standing time between embankment filling stages.

\section{Site Description}

The selected case study for numerical modeling was a road embankment of National Highway 320 in Hunan, China, which was constructed over deep soft soil. The underground conditions of the site were reported in Zhou et al.'s work [24]. The geotechnical profile is characterized by an upper soft soil layer extending to a depth of 6-7 m. This soft layer is distributed with mainly silty clay, which has extremely high water content and very low shear strength. Below the soft layer is a layer of coarse sand, which is possible to induce liquefaction. Therefore, both drainage and compaction should be taken into account in the subgrade improvement. 
The subgrade reinforcement program, geogrid-encased stone column, and sand cushion were adopted in this project. The stone columns were $0.8 \mathrm{~m}$ in diameter and $6.5 \mathrm{~m}$ in length, with a spacing of $1.5 \mathrm{~m}$ and area replacement rate of $5.6 \%$. Besides, the stone columns were encased with geogrid, the encasement length was $1.5 \mathrm{~m}$, approximately twice diameters of the stone column, and the rest $5 \mathrm{~m}$ of the stone column was not encased. The sand cushion was $0.8 \mathrm{~m}$ in thickness, which was used for horizontal drainage to accelerate the consolidation of the subgrade.

The filling process consists of three stages, as shown in Figure 2. The filling height of each stage is $2 \mathrm{~m}$. The duration time of filling is $6 \mathrm{~d}, 8 \mathrm{~d}$, and $10 \mathrm{~d}$ for stage 1 , stage 2 , and stage 3, respectively. The standing time is $10 \mathrm{~d}$ and $12 \mathrm{~d}$ between stages 1-2 and stages 2-3, respectively. In this study, the duration of days $0-46$ is regarded as the construction stage, and the duration of days $47-170$ is the postconstruction stage.

\section{Numerical Simulation}

3.1. Numerical Model. The finite element program Plaxis 2D was adopted to analyze the settlement behavior of the geogrid-encased columns-supported embankment over soft soil. The designed finite element model is shown in Figure 3. The soil, gravel, and geogrid were modelled using a nonlinear elastic-plastic constitutive model with Mohr-Coulomb yield criterion and the nonassociated flow rule. All of the analyses were performed using meshes made up of four 15-node triangles within each rectangle.

The interface strength reduction factor $\left(R_{\text {inter }}\right)$ was used to simulate the interfacial interactions between geogrid and stone column as well as geogrid and surrounding soil. The value of $R_{\text {inter }}$ was determined in reference to Wu and Hong [25]. The geocell and the encased sand were treated as a composite cell to simulate the reinforcement of geocell in sand cushion. This manner can not only simulate the mechanical characteristics of geocell layers but also simplify the modelling steps and reduce the contact surface between geocell and sand [26]. The deformation of bottom boundary was fixed in both horizontal and vertical directions. The deformation of the two side boundaries was fixed in the horizontal direction but was allowed to move freely in the vertical direction.

3.2. Material Properties. As reported in the work of Madhavi [27], the geocell-sand composite can be treated as an equivalent soil layer with cohesive strength greater than the encased soil and angle friction angle the same as the encased soil. The induced cohesion in the soil, $c_{r}$, is related to the increase in the confining pressure on the soil due to geocell reinforcement, which can be obtained through the following equation:

$$
c_{r}=\frac{\Delta \sigma_{3} \sqrt{K_{p}}}{2},
$$

where $K_{p}$ is the coefficient of passive Earth pressure, and it can be valued as $0.58 ; \Delta \sigma_{3}$ is the additional confining

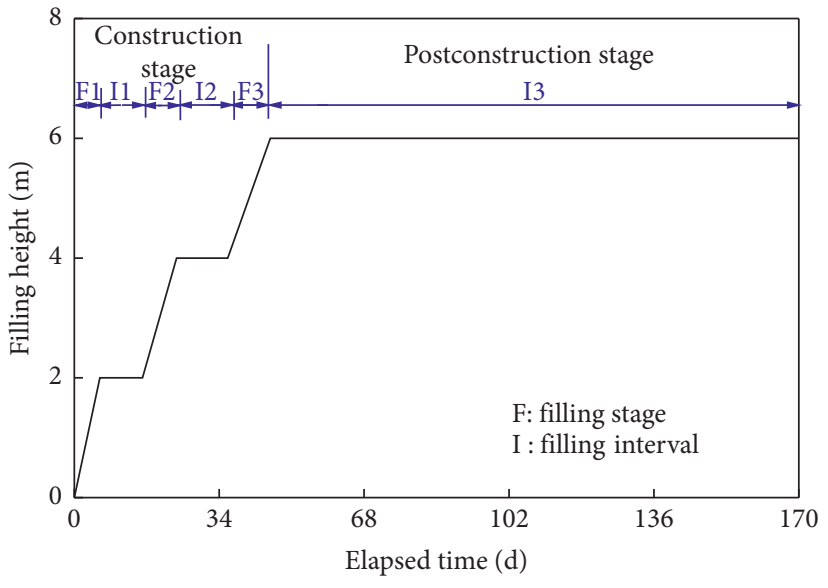

FIGURE 2: Filling process of the embankment.

pressure due to geocell reinforcement, which can be calculated via the following equation:

$$
\Delta \sigma_{3}=\frac{2 M\left[\left(1-\sqrt{1-\varepsilon_{a}}\right) /\left(1-\varepsilon_{a}\right)\right]}{D_{0}},
$$

where $\varepsilon_{a}$ is the axial strain at failure state, and it can be valued as $0.25 ; M$ is the secant modulus of the geocell material at the axial strain of $\varepsilon_{a}$; $D_{0}$ is the initial diameter of the geocell, and the value is $0.2256 \mathrm{~m}$ in this study.

Based on triaxial compression tests on geocell-encased sand, Madhavi [26] proposed the following empirical equation to express Young's modulus of geocell-reinforced sand $\left(E_{g}\right)$ :

$$
E_{g}=4\left(\sigma_{3}\right)^{0.7}\left(K_{u}+200 \bar{M}^{0.16}\right),
$$

where $K_{u}$ is the dimensionless modulus parameter of the unreinforced sand, and it can be valued as $0.25 ; \bar{M}$ is the secant modulus of the geocell material, and the value should be corresponded to the average strain of $2.5 \%$ in the loadelongation response of the geocell material; here the value is $160 \mathrm{kN} / \mathrm{m} ; \sigma_{3}$ is the confining pressure, and here the value is $37 \mathrm{kPa}$.

Based on the above method, the cohesion and modulus of the geocell-sand composite can be obtained. The physical and mechanical parameters of embankment fill, silty clay, sand, and gravel were obtained from laboratory tests reported in the work of Zhou et al. [24]. The values of $R_{\text {inter }}$ were referenced from the work of $\mathrm{Wu}$ and Hong [25]. All the parameters used in present numerical analysis are summarized in Table 1.

3.3. Parametric Study. The designed cases in present numerical analysis are shown in Table 2. Control case was carried out on the actual engineering condition to verify the reliability and accuracy of the numerical model and adopted parameters. Case 1 was conducted by varying the number of geocell layers to investigate the effect of geocell layers in sand cushion on the settlement behavior of the subgrade. In Case 2 , the encasement length of GESC was varied from 1D (one time the stone column, i.e., $0.8 \mathrm{~m}$ ) to $8 \mathrm{D}$ (full encasement, 


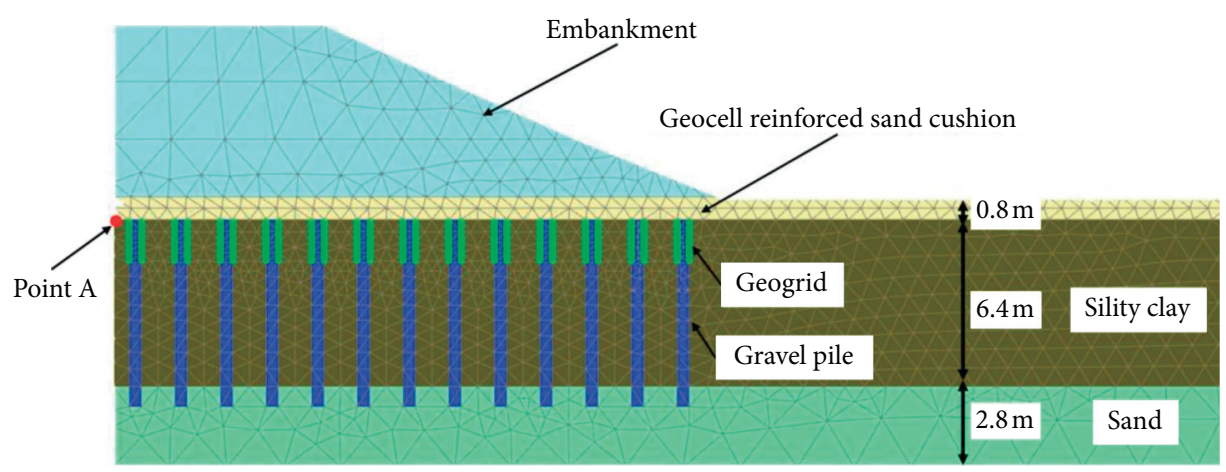

FIGURE 3: Designed numerical model.

Table 1: Physical and mechanical properties of the materials.

\begin{tabular}{|c|c|c|c|c|c|}
\hline Parameter & Embankment fill & Geocell-sand composite & Silty clay & Sand & Gravel \\
\hline Natural unit weight $\gamma\left(\mathrm{kN} / \mathrm{m}^{3}\right)$ & 17 & 19 & 14 & 20 & 18 \\
\hline Saturated unit weight $\gamma_{\text {sat }}\left(\mathrm{kN} / \mathrm{m}^{3}\right)$ & 19 & 20 & 15 & 21 & 21 \\
\hline Elasticity modulus $E(\mathrm{MPa})$ & 15 & 42 & 2.8 & 26 & 50 \\
\hline Poisson's ratio $\mu$ & 0.3 & 0.3 & 0.35 & 0.3 & 0.3 \\
\hline Cohesion $c(\mathrm{kPa})$ & 15 & 42 & 14 & 10 & 0 \\
\hline Friction angle $\varphi\left({ }^{\circ}\right)$ & 23 & 30 & 17 & 30 & 35 \\
\hline Interface strength reduction factor $R_{\text {inter }}$ & 0.65 & 0.65 & 0.58 & 0.58 & 0.58 \\
\hline
\end{tabular}

TABLE 2: Designed cases in the finite-element simulations.

\begin{tabular}{lccc}
\hline Cases & Geocell layer in sand cushion & Encasement length of stone column & Standing time between filling stages \\
\hline Control case & None & $2 \mathrm{D}$ & Actual engineering condition \\
Case 1 & One/two & $2 \mathrm{D}$ & Actual engineering condition \\
Case 2 & None & $1 \mathrm{D} \sim 8 \mathrm{D}$ & Actual engineering condition \\
Case 3 & None & $2 \mathrm{D}$ & $+10 \mathrm{~d} /+15 \mathrm{~d} /+20 \mathrm{~d} /+25 \mathrm{~d}$ \\
\hline
\end{tabular}

$\mathrm{D}$ refers to the diameter of the stone column.

i.e., $6.4 \mathrm{~m}$ ) in order to study the influence of encasement length on the settlement behavior of the subgrade. The influences of standing time between filling stages on the subgrade settlement and pore water pressure were analyzed in Case 3; the filling interval was extended by 10 days, 15 days, 20 days, and 25 days in sequence on the basis of the control case.

\section{Results and Analysis}

4.1. Validation of Simulation Results. Figure 4 shows the temporal variation of surface settlement at the center of the subgrade (point A). In the construction stage, the simulating settlements at the end of F1 (day 6), I1 (day 16), F2 (day 24), I2 (day 36), and F3 (day 46) are $16.0 \mathrm{~cm}, 25.4 \mathrm{~cm}, 49.2 \mathrm{~cm}$, $58.5 \mathrm{~cm}$, and $80.8 \mathrm{~cm}$, respectively, and the corresponding field monitoring settlements are $11.7 \mathrm{~cm}, 25.7 \mathrm{~cm}, 41.5 \mathrm{~cm}$, $54.2 \mathrm{~cm}$, and $67.3 \mathrm{~cm}$. In the postconstruction stage, after 124 days following F3, the simulating settlement further developed to $96.1 \mathrm{~cm}$, and the field monitoring result was $94.4 \mathrm{~cm}$. It is observed that the simulated settlements are slightly larger than the measured results in the filling interval stages, that is, I1, I2, and I3. The reason can be explained as follows. In the numerical analysis, the subgrade soil was assumed to be homogeneous and be classified into layers, that is, an ideal state. In fact, the distribution of the subgrade soil was inhomogeneous and very complex in the field site. Therefore, the seepage path would be more flexural in the field site, which results in a lower hydraulic coefficient of the subgrade soil and further leads to a delay of the consolidation settlement in the filling interval stages. On the whole, the simulating results are quite comparable to the field monitoring data, which indicates that the designed numerical model and adopted parameters in this paper are acceptably accurate.

4.2. Influence of Geocell Layers in Sand Cushion on the Subgrade Settlement. Figure 5 shows the temporal variation of surface settlement at the center of the subgrade (point A) when installing different layers of geocell in sand cushion. In the construction stage, the settlements increased to $73.5 \mathrm{~cm}$ and $66.7 \mathrm{~cm}$, respectively, for the conditions of installation of one-layer and two-layer geocell in sand cushion, being $9.0 \%$ and $17.5 \%$ smaller than the control case (no geocell layer). After 124 days following F3, the postconstruction settlements were $12.6 \mathrm{~cm}$ and $9.6 \mathrm{~cm}$ when installing one-layer and two-layer geocell, respectively, which are $19.2 \%$ and $38.5 \%$ smaller than the control case. It is observed that the embedment of geocell in sand cushion can significantly 


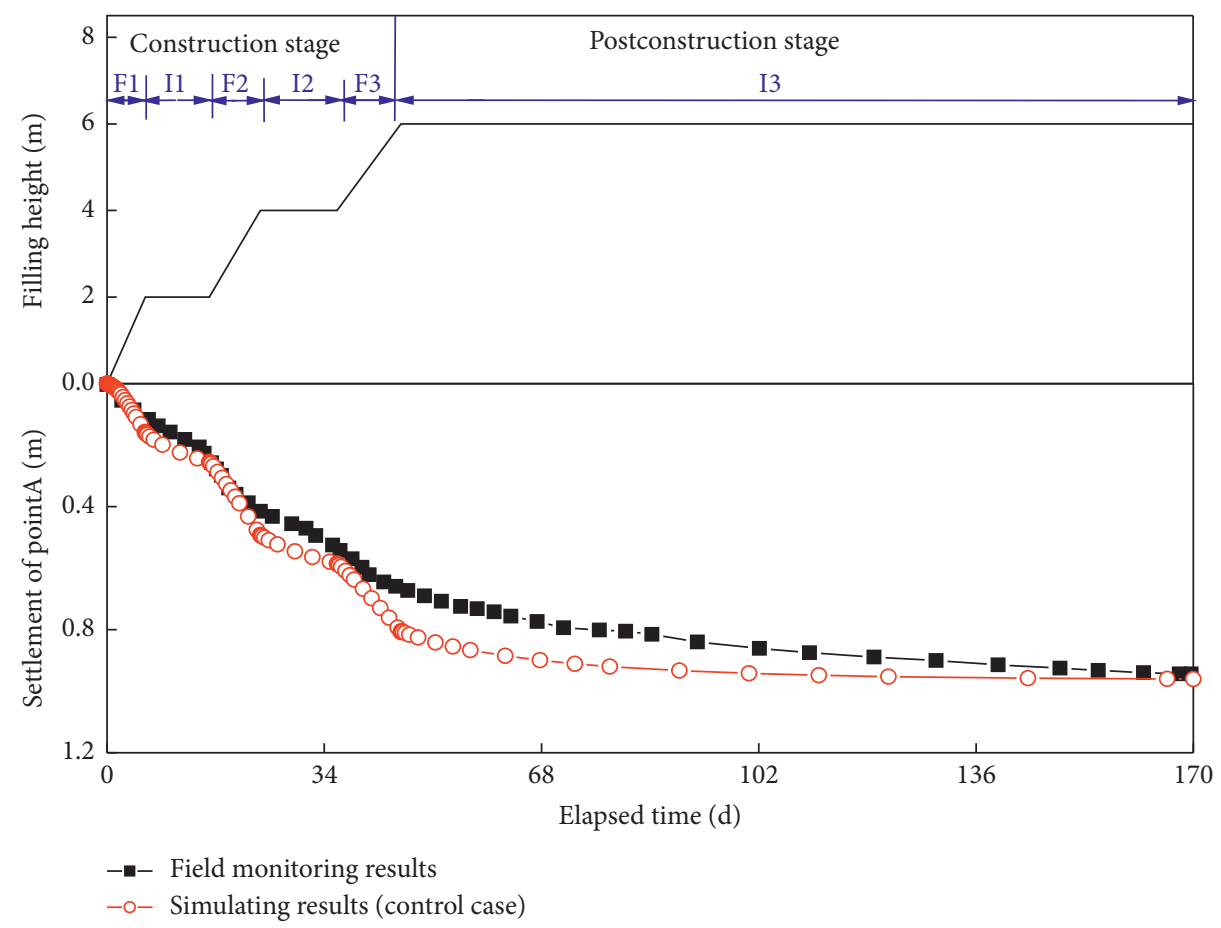

FIGURE 4: Comparison between monitoring and simulating results for the settlement of point A.

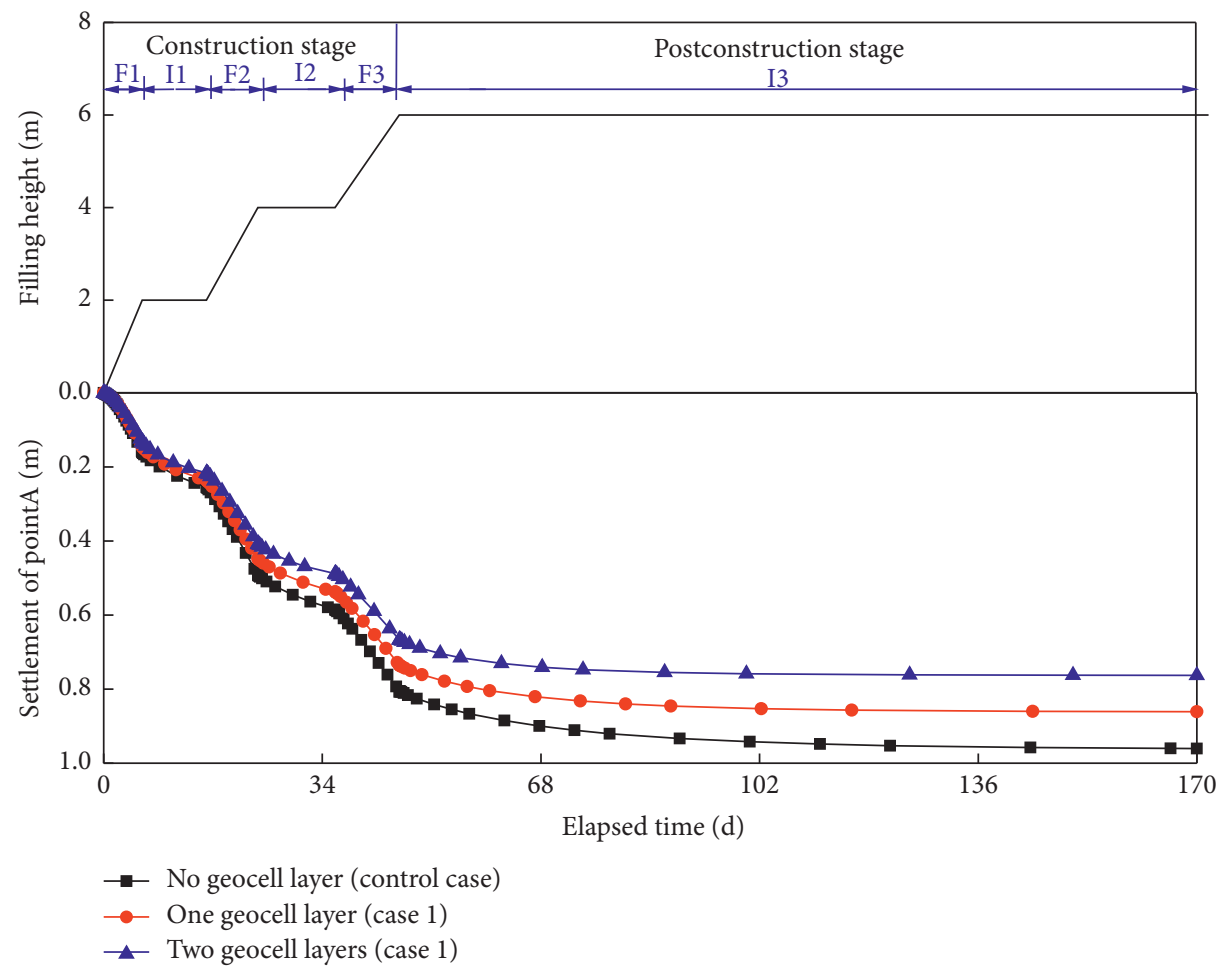

Figure 5: Influence of geocell layer in sand cushion on the settlement of point A.

reduce both the construction settlement and postconstruction settlement of the subgrade.

Figure 6 shows the differential settlement of the subgrade on day 170 under the conditions of installing different layers of geocell in sand cushion. When there is no geocell layer in the sand cushion, the differential settlement between the center and the edge of the subgrade was about $73.0 \mathrm{~cm}$. When there is one geocell layer installed in the sand cushion, the differential settlement was about $66.0 \mathrm{~cm}$, being $9.6 \%$ lower than the control case. The differential settlement was 


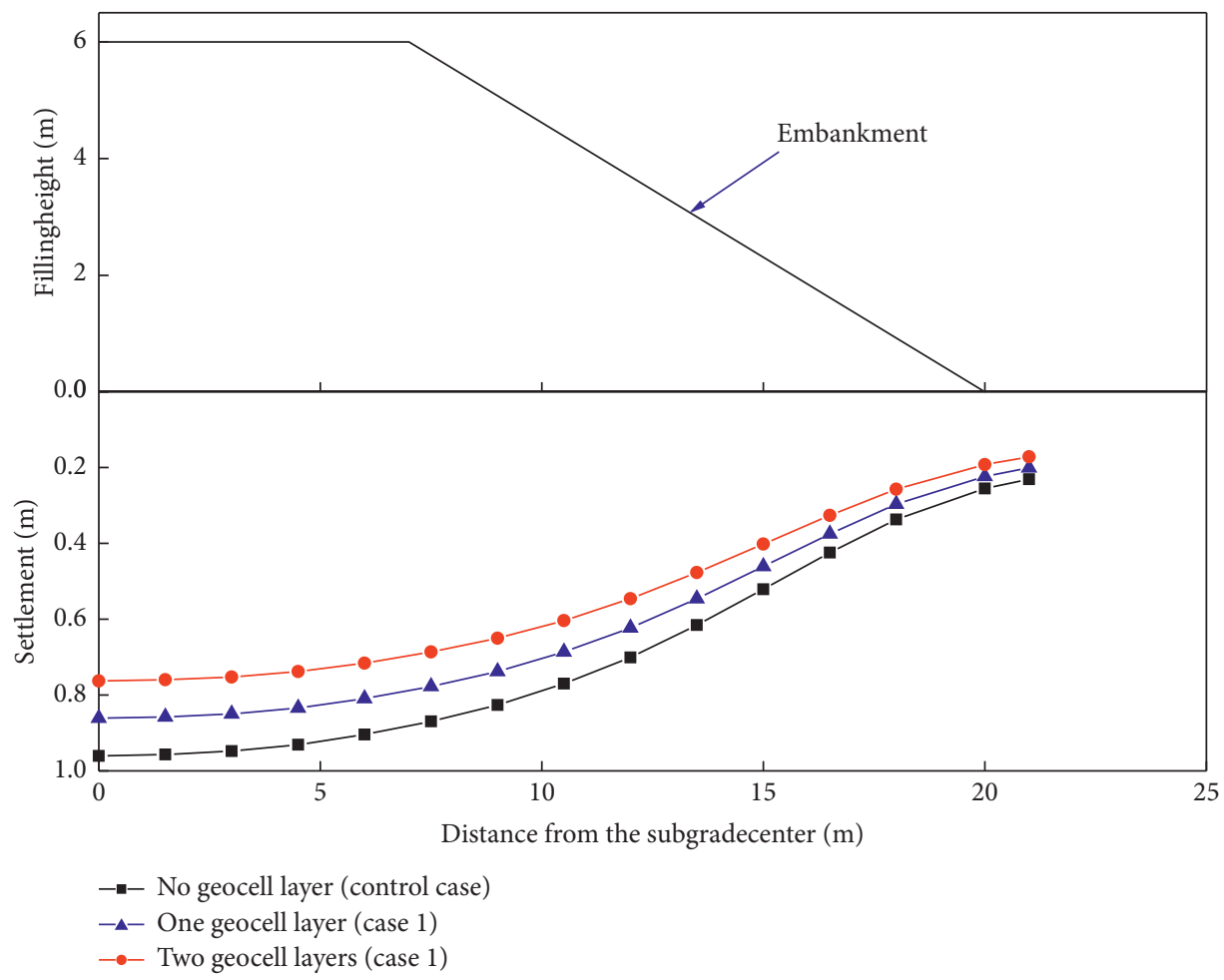

FIgURE 6: Influence of geocell layer in sand cushion on the differential settlement.

about $59.1 \mathrm{~cm}$ when installing two-layer geocell, being $19.0 \%$ lower than the control case. It can be seen that the embedment of geocell in sand cushion can effectively reduce the differential settlement of the subgrade.

\subsection{Influence of Encasement Length of Stone Column on the} Subgrade Settlement and Column Lateral Deformation. Figure 7 shows the temporal variation of surface settlement at the center of the subgrade (point A) with different encasement length of the stone column. In the construction stage, the settlements increased to $88.8 \mathrm{~cm}$, $80.8 \mathrm{~cm}, 75.3 \mathrm{~cm}, 70.7 \mathrm{~cm}, 67.9 \mathrm{~cm}, 65.0 \mathrm{~cm}, 62.8 \mathrm{~cm}$, and $60.2 \mathrm{~cm}$ with respect to the encasement length of $1 \mathrm{D}, 2 \mathrm{D}$, $3 \mathrm{D}, 4 \mathrm{D}, 5 \mathrm{D}, 6 \mathrm{D}, 7 \mathrm{D}$, and $8 \mathrm{D}$ (full encasement). In the postconstruction stage, after 124 days following F3, the settlements further developed to $104.7 \mathrm{~cm}, 96.1 \mathrm{~cm}$, $88.5 \mathrm{~cm}, 82.0 \mathrm{~cm}, 77.9 \mathrm{~cm}, 74.1 \mathrm{~cm}, 70.8 \mathrm{~cm}$, and $67.9 \mathrm{~cm}$ for the encasement length of $1 \mathrm{D}, 2 \mathrm{D}, 3 \mathrm{D}, 4 \mathrm{D}, 5 \mathrm{D}, 6 \mathrm{D}, 7 \mathrm{D}$, and $8 \mathrm{D}$, respectively, corresponding to the postconstruction settlements of $15.9 \mathrm{~cm}, 15.3 \mathrm{~cm}, 13.2 \mathrm{~cm}$, $11.3 \mathrm{~cm}, 10.0 \mathrm{~cm}, 9.1 \mathrm{~cm}, 8.0 \mathrm{~cm}$, and $7.7 \mathrm{~cm}$. It is seen that the increase of encasement length of the stone column results in the reductions of both construction and postconstruction settlements of the subgrade. It is also observed that the settlement decreased more significantly with the encasement length increasing from $1 \mathrm{D}$ to $4 \mathrm{D}$; however, a further increase of the encasement length resulted in a slow decrease of the settlement. Therefore, the encasement length of the stone column up to four times of the diameter of the column is found to be adequate in reducing the settlement based on the consideration of performance and economy.

Figure 8 shows the differential settlement of the subgrade on day 170 with different encasement length of the stone column. When the encasement length was $1 \mathrm{D}$, the differential settlement between the center and the edge of subgrade was about $78.1 \mathrm{~cm}$. If the encasement length increased to $4 \mathrm{D}$, the differential settlement was about $61.9 \mathrm{~cm}$, and the reduction rate was about $20.7 \%$ regarding $1 \mathrm{D}$ condition. If the encasement length further increased to $8 \mathrm{D}$, the differential settlement was about $51.7 \mathrm{~cm}$, corresponding to a reduction rate of $33.8 \%$ when compared to $1 \mathrm{D}$ condition. It can be seen that the differential settlement of the subgrade gradually decreases significantly with the increase of the encasement length of the stone column.

Taking the stone column at the center of the subgrade as an example, the lateral deformations of the stone column with different encasement lengths are shown in Figure 9. The lateral deformations were calculated at day 170, that is, 124 days after the completion of the embankment filling. It is observed that the maximum lateral deformation occurs at the position of about $2 \mathrm{D}$ from the top of the stone column and it decreases gradually with the increase of encasement length of the stone column. When the encasement length is $1 \mathrm{D}$, the maximum lateral deformation is about $9.20 \mathrm{~cm}$. When the encasement length increases to $4 \mathrm{D}$ and $8 \mathrm{D}$, the maximum lateral deformation is about $3.67 \mathrm{~cm}$ and $2.75 \mathrm{~cm}$, respectively, corresponding to a reduction rate of $60.08 \%$ and $70.08 \%$ when compared to $1 \mathrm{D}$ condition. It is seen that the lateral deformation decreased more significantly when the encasement length increased from $1 \mathrm{D}$ to $4 \mathrm{D}$ compared to 


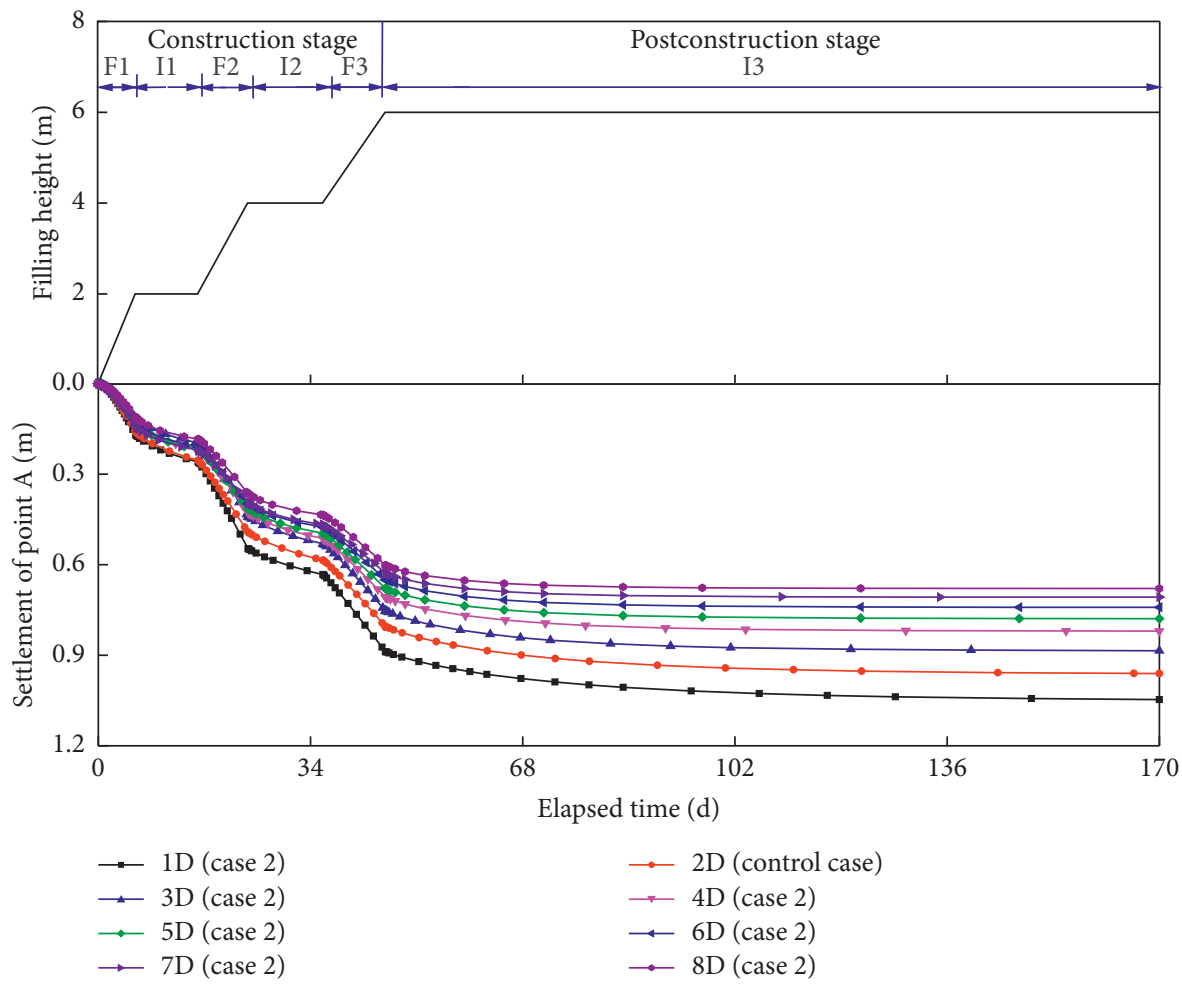

Figure 7: Influence of encasement length on the settlement of point A.

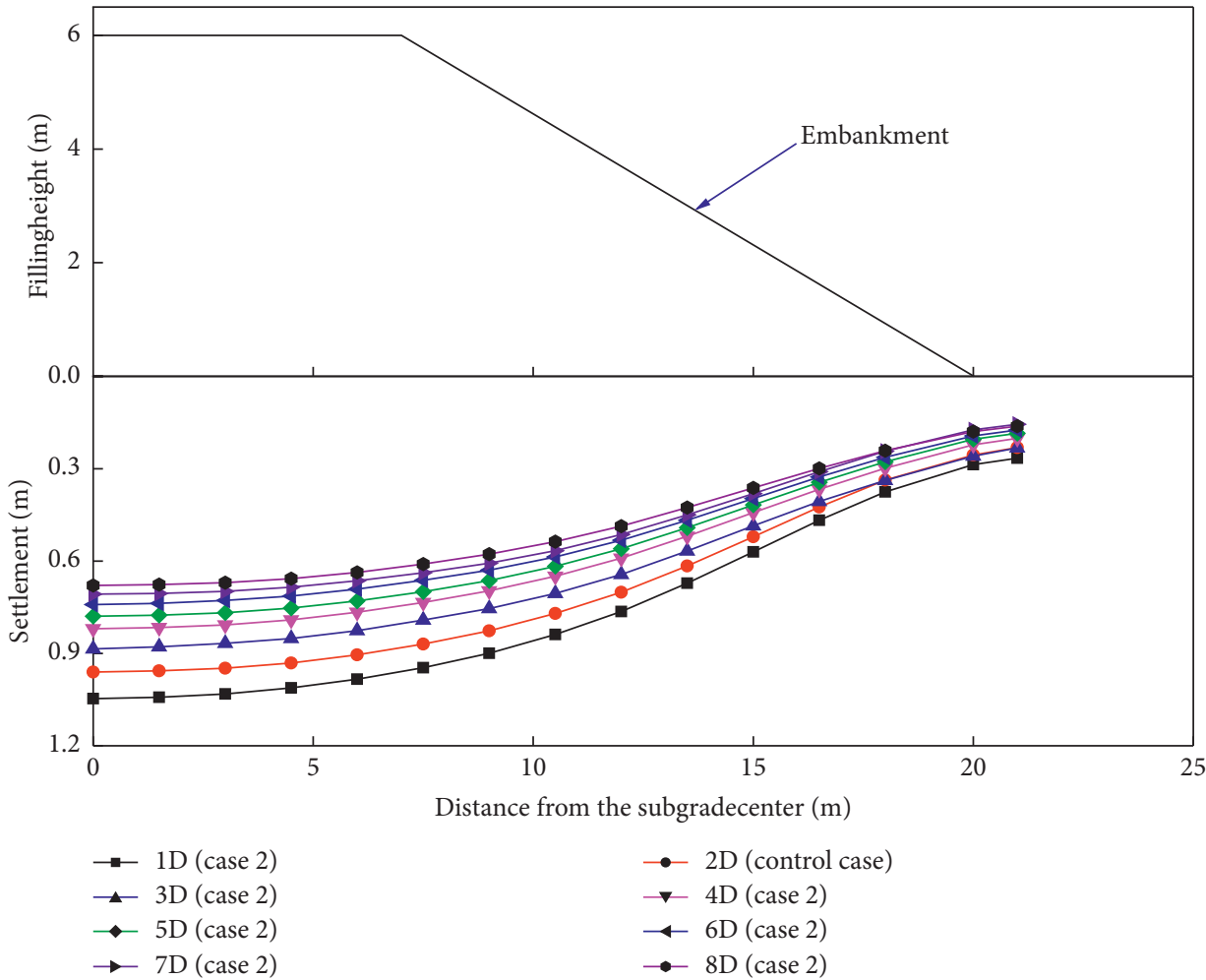

FIgURE 8: Influence of encasement length on the differential settlement. 


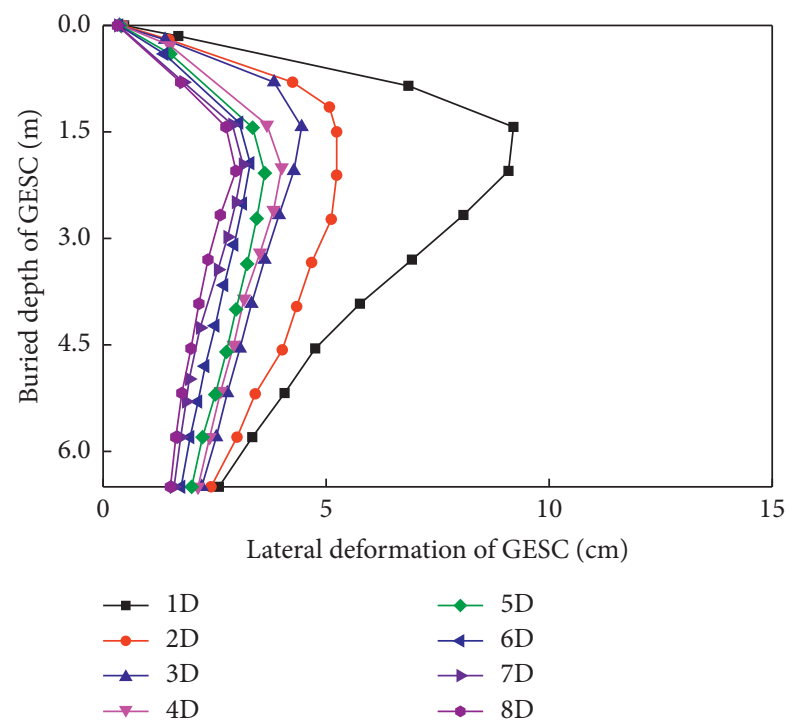

Figure 9: Influence of encasement length on the lateral deformation.

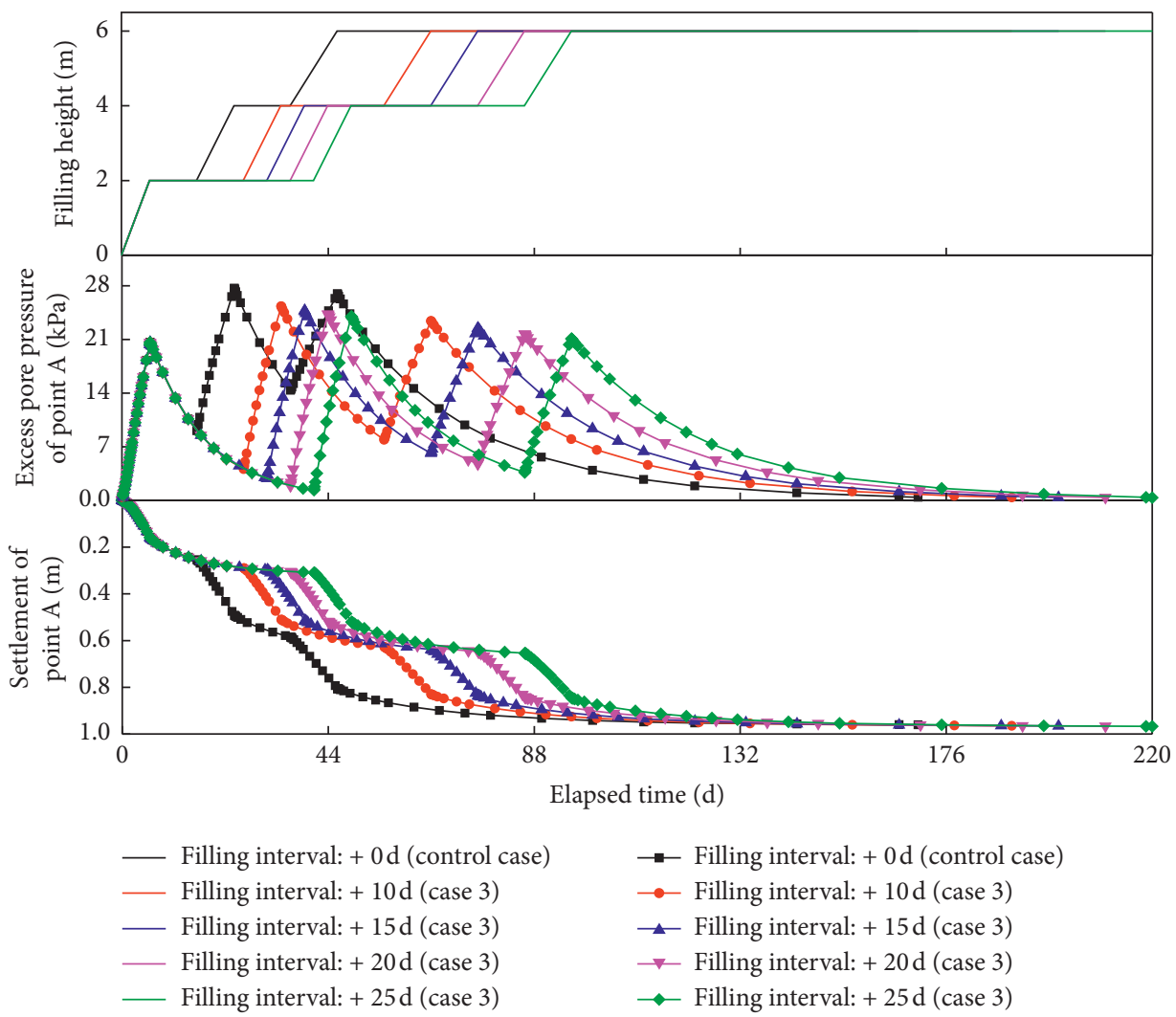

FIgURE 10: Influence of filling interval on excess pore water pressure and settlement of point A.

that from $4 \mathrm{D}$ to $8 \mathrm{D}$. Therefore, the encasement length of the stone column up to $4 \mathrm{D}$ is found to be adequate in reducing the lateral deformation of the column when considering both the performance and economy.

4.4. Influence of Filling Interval on the Subgrade Settlement. Figure 10 shows the temporal variation of surface settlement at the center of the subgrade (point A) with different standing time between filling stages. In the construction stage, the settlement developed rapidly and the excess pore water pressure increased sharply during the filling process, and the settlement developed slowly and the excess pore water pressure gradually dissipated in the standing period. In this stage, the settlements developed to $83.0 \mathrm{~cm}, 83.6 \mathrm{~cm}$, $84.1 \mathrm{~cm}$, and $84.5 \mathrm{~cm}$, respectively, for the filling interval extended by 10 days, 15 days, 20 days, and 25 days, being 


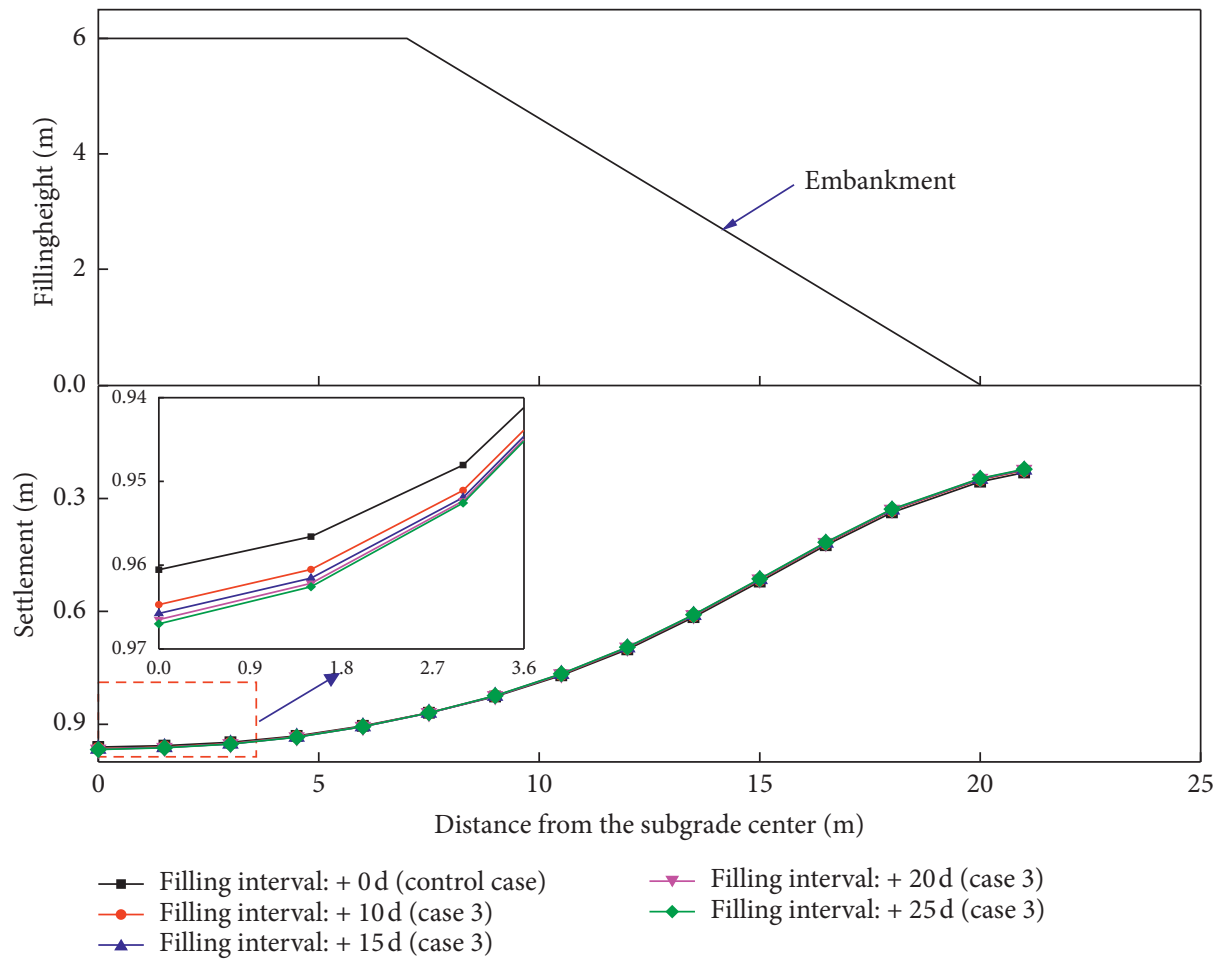

Figure 11: Influence of filling interval on the differential settlement.

$3.1 \%, 3.9 \%, 4.5 \%$, and 5.0\% larger than the control case. In the postconstruction stage, the settlement further developed to a stable value and the excess pore water pressure gradually dissipated to approximately zero. The postconstruction settlements were $13.4 \mathrm{~cm}, 13.0 \mathrm{~cm}, 12.6 \mathrm{~cm}$, and $12.2 \mathrm{~cm}$, respectively, for the filling interval extended by 10 days, 15 days, 20 days, and 25 days, being 14.1\%, 16.7\%, 19.6\%, and $21.8 \%$ smaller than the control case. It is seen that the extension of the filling interval will promote the consolidation of subgrade soil in the construction stage, which results in an increase in the construction settlement and a reduction in the postconstruction settlement.

Figure 11 shows the differential settlement of the subgrade with different standing time between filling stages. The settlements were calculated at the time point of 124 days after the completion of the embankment filling. The differential settlements between the center and the edge of the subgrade were about $73.9 \mathrm{~cm}, 74.1 \mathrm{~cm}, 74.4 \mathrm{~cm}$, and $74.5 \mathrm{~cm}$, respectively, for the filling interval extended by 10 days, 15 days, 20 days, and 25 days; the corresponding increase rates were about $1.2 \%, 1.5 \%, 1.9 \%$, and $2.1 \%$ when compared to the control case. It can be seen that the extension of the standing time between filling stages has negligible influence on the differential settlement of the subgrade.

\section{Discussion}

Composite compression modulus method is one of the available methods to compute the settlement of GESC supported composite foundation, and the calculation equation [28] is presented as follows:

$$
\begin{aligned}
S & =\sum_{i=1}^{n} \frac{\Delta p_{i}}{E_{\mathrm{csi}}} H_{i}, \\
E_{\mathrm{cs}} & =m E_{\mathrm{ps}}+(1-m) E_{\mathrm{ss}},
\end{aligned}
$$

where $S$ is final settlement of composite foundation; $E_{\mathrm{ss}}$ is compression modulus of the soil; $E_{\mathrm{ps}}$ is compression modulus of the column; $E_{\mathrm{cs}}$ is composite compression modulus of the foundation; $m$ is area replacement ratio; $n$ are numbers of calculation layers; $H_{i}$ is thickness of soil layer $i$; $D p_{i}$ is additional stress of soil layer $i$. From the above equation, the following issues were discussed:

(1) The embedment of geocell would provide reinforcement via the restriction of soil movement and the concentration of stresses within the geocell, hence increasing the stiffness of the sand cushion [29]. In addition, the confinement provided by geocells improves the distribution of additional stress over the subgrade [30] and decreases more at the center and decreases less at the side [31]. As a result, both the center settlement and differential settlement on the subgrade surface reduce [30].

(2) The lateral deformation of the stone column decreased due to the additional confining stress provided by the geogrid encasement, and, therefore, the compression modulus of the column increases as well as the composite compression modulus of the foundation $[22,32]$. As a result, the larger the encasement length of the column, the smaller the 
construction and post-construction settlements of the subgrade. However, the column encasement cannot significantly affect the embankment pressure distribution on subgrade surface; hence, the encasement length of the column has small influence on the differential settlement of the subgrade [33].

(3) The extension of standing time between filling stages would promote the dissipation of the excess pore pressure and increase the settlement induced by soil consolidation in the construction stage. As a result, the compression modulus of soil increases, as well as the composite compression modulus of the foundation at the end of the construction stage [1, 23]. Therefore, the longer filling interval, the larger the construction settlement and the smaller the postconstruction settlement of the subgrade. However, the extension of filling interval cannot affect the additional stress on the subgrade surface, and, therefore, it has negligible influence on the differential settlement of the subgrade.

\section{Conclusions}

This study conducted numerical analysis on the settlement behavior of a soft subgrade reinforced by geogrid-encased stone column and geocell-embedded sand cushion, and the main findings were presented as follows:

(1) The simulating settlement was in good agreement with the field monitoring data, which indicates that the designed model and adopted parameters are reasonable.

(2) The embedment of geocell in sand cushion reduced the construction settlement, the postconstruction settlement, and the differential settlement. The geocell embedment will increase the stiffness of sand cushion and, therefore, adjust the embankment pressure to distribute more uniformly on subgrade surface.

(3) The increase in encasement length of the stone column resulted in the smaller construction settlement, postconstruction settlement, and differential settlement. The additional confinement provided by the encasement increases the compression modulus of the column as well as the composite foundation. The maximum lateral deformation occurred at the position of about 2D (two times the column diameter) from the top of the stone column, and it decreased more significantly when the encasement length increased from $1 \mathrm{D}$ to $4 \mathrm{D}$ compared to that from $4 \mathrm{D}$ to $8 \mathrm{D}$. The encasement length up to $4 \mathrm{D}$ is found to be adequate in reducing the subgrade settlement and the column lateral deformation based on the consideration of performance and economy.

(4) The extension of the standing time between embankment filling stages increased the construction settlement due to the promotion of soil consolidation, while it decreased the postconstruction settlement. However, the extension of filling interval had little influence on the differential settlement, and it would lead to a delay of the embankment construction.

\section{Data Availability}

The data used to support the findings of this study are available from the corresponding author upon request.

\section{Conflicts of Interest}

The authors declare that there are no conflicts of interest regarding the publication of this paper.

\section{Acknowledgments}

The authors are very grateful for the financial support of the Science Technology Department of Zhejiang Province (Grant no. 2019C03107).

\section{References}

[1] M. G. Bozkurt and D. Fratta, "Deformation response of soft foundation soils under tall embankments-a numerical analysis," in Proceedings of the Geo-Congress 2014, Georgia, AT, USA, February 2014.

[2] W. F. V. Impe, "Soil improvement techniques and their evolution," Animal Ence Papers \& Reports, vol. 20, no. 1, pp. 169-178, 1989.

[3] Q. Tang, Y. Zhang, Y. Gao, and F. Gu, "Use of cementchelated, solidified, municipal solid waste incinerator (MSWI) fly ash for pavement material: mechanical and environmental evaluations," Canadian Geotechnical Journal, vol. 54, no. 11, pp. 1553-1566, 2017.

[4] Q. Tang, F. Gu, H. Chen, C. Lu, and Y. Zhang, "Mechanical evaluation of bottom ash from municipal solid waste incineration used in roadbase," Advances in Civil Engineering, vol. 2018, Article ID 5694908, 8 pages, 2018.

[5] Y. D. Zhou, L. L. Pan, Q. Tang, Y. Zhang, N. Yang, and C. Lu, "Evaluation of carbonation effects on cement solidified contaminated soil used in road subgrade," Advances in Materials Science and Engineering, vol. 2018, Article ID 5271324, 15 pages, 2018.

[6] Y. C. Huang, J. Chen, S. J. Shi, B. Li, J. L. Mo, and Q. Tang, "Mechanical properties of municipal solid waste incinerator (MSWI) bottom ash as alternatives of subgrade materials," Advances in Civil Engineering, vol. 2020, Article ID 9254516, 11 pages, 2020.

[7] S. Murugesan and K. Rajagopal, "Geosynthetic-encased stone columns: numerical evaluation," Geotextiles and Geomembranes, vol. 24, no. 6, pp. 349-358, 2006.

[8] E. R. Orekanti and G. V. Dommaraju, "Load-settlement response of geotextile encased laterally reinforced granular piles in expansive soil under compression," International Journal of Geosynthetics and Ground Engineering, vol. 5, no. 3, p. 17, 2019.

[9] J. M. McKenna, W. A. Eyre, and D. R. Wolstenholme, "Performance of an embankment supported by stone columns in soft ground," Géotechnique, vol. 25, no. 1, pp. 51-59, 1975.

[10] S. S. Gue and Y. C. Tan, "Failures of ground improvement works in soft ground," Elsevier Geo-Engineering Book Series, vol. 3, pp. 665-680, 2005. 
[11] D. A. Greenwood, "Load tests on stone columns," Deep Foundation Improvements: Design Construction and Testing, ASTM, West Conshohocken, PA, USA, pp. 148-171, 1991.

[12] M. Y. Fattah and Q. G. Majeed, "A study on the behavior of geogrid encased capped stone columns by the finite element method," International Journal of GEOMATE, vol. 3, no. 1, pp. 343-350, 2012.

[13] M. Y. Fattah and Q. G. Majeed, "Finite element analysis of geogrid encased stone columns," Geotechnical and Geological Engineering, vol. 30, no. 4, pp. 713-726, 2012.

[14] M. Y. Fattah, B. S. Zabar, and H. A. Hassan, "Soil arching analysis in embankments on soft clays reinforced by stone columns," Structural Engineering and Mechanics, vol. 56, no. 4, pp. 507-534, 2015.

[15] M. Y. Fattah, B. S. Zabar, and H. A. Hassan, "Experimental analysis of embankment on ordinary and encased stone columns," International Journal of Geomechanics, vol. 16, no. 4, Article ID 04015102, 2016.

[16] S. F. Kwa, E. S. Kolosov, and M. Y. Fattah, "Ground improvement using stone column construction encased with geogrid," Construction of Unique Buildings and Structures, vol. 3, no. 66, pp. 49-59, 2018.

[17] S. N. Malarvizhi and K. Ilamparuthi, "Load versus settlement of clay bed stabilized with stone and reinforced stone columns," in Proceedings of the 3rd Asian Regional Conference on Geosynthetics, Seoul, Korea, 2004.

[18] M. Gu, M. Zhao, L. Zhang, and J. Han, "Effects of geogrid encasement on lateral and vertical deformations of stone columns in model tests," Geosynthetics International, vol. 23, no. 2, pp. 100-112, 2016.

[19] M. Hajiazizi and M. Nasiri, "Experimental and numerical investigation of reinforced sand slope using geogird encased stone column," Civil Engineering Infrastructures Journal, vol. 52, no. 1, pp. 85-100, 2019.

[20] T. Ayadat and A. M. Hanna, "Encapsulated stone columns as a soil improvement technique for collapsible soil," Proceedings of the Institution of Civil Engineers-Ground Improvement, vol. 9, no. 4, pp. 137-147, 2005.

[21] C. Yoo and D. Lee, "Performance of geogrid-encased stone columns in soft ground: full-scale load tests," Geosynthetics International, vol. 19, no. 6, pp. 480-490, 2012.

[22] S. T. Kadhim, R. L. Parsons, and J. Han, "Three-dimensional numerical analysis of individual geotextile-encased sand columns with surrounding loose sand," Geotextiles and Geomembranes, vol. 46, no. 6, pp. 836-847, 2018.

[23] M. S. Almeida, I. Hosseinpour, M. Riccio, and D. Alexiew, "Behavior of geotextile-encased granular columns supporting test embankment on soft deposit," Journal of Geotechnical and Geoenvironmental Engineering, vol. 141, no. 3, Article ID 04014116, 2015

[24] Z. G. Zhou, Q. S. Zhang, and J. L. Zheng, "Analysis of mechanism of improved ground with stone columns reinforced by geogrids," China Civil Engineering Journal, vol. 31, no. 1, pp. 21-26, 1998.

[25] C.-S. Wu and Y.-S. Hong, "Laboratory tests on geosyntheticencapsulated sand columns," Geotextiles and Geomembranes, vol. 27, no. 2, pp. 107-120, 2009.

[26] G. L. Madhavi and K. Rajagopal, "Parametric finite element analyses of geocell-supported embankments," Canadian Geotechnical Journal, vol. 44, no. 8, pp. 917-927, 2007.

[27] G. L. Madhavi, "Investigations on the behaviour of geocell supported embankments," Ph.D. thesis, Indian Institute of Technology, Madras, India, 2000.
[28] Ministry of Housing and Urban Rural Development of the People's Republic of China, "Technical code for composite foundation (GB/T50783-2012)," China Planning Press, Beijing, China, 2012.

[29] M. Y. Fattah, R. R. Al-Omari, and H. A. Ali, "Numerical simulation of the treatment of soil swelling using grid geocell columns," Slovak Journal of Civil Engineering, vol. 23, no. 2, pp. 9-18, 2015.

[30] M. Y. Fattah, W. H. Hassan, and S. E. Rasheed, "Effect of geocell reinforcement above buried pipes on surface settlement," International Review of Civil Engineering (IRECE), vol. 9, no. 2, pp. 86-90, 2018.

[31] Y. F. Hao, "Study on the influences of subbase properties on pavement additional stress," Modern Transportation Technology, vol. 10, no. 5, pp. 11-14, 2013.

[32] M. Ghazavi and J. Nazari Afshar, "Bearing capacity of geosynthetic encased stone columns," Geotextiles and Geomembranes, vol. 38, pp. 26-36, 2013.

[33] H. G. Kempfert and M. Raithel, "Soil improvement and foundation systems with encased columns and reinforced bearing layers," Elsevier Geo-Engineering Book Series, vol. 3, pp. 923-946, 2005. 